\title{
SOME NORTH AMERICAN SPECIES OF CHÆTOPLEUROPHORA (DIPTERA, PHORIDÆ)
}

\author{
By Charles T. Brues
}

Biological Laboratories, Harvard University

A collection of Phoridæ recently sent to me from Cornell University for identification contains an interesting new species of Chætopleurophora. To the description of this which is given below, I have added generic references for several other American species.

\section{Chotopleurophora Schmitz.}

\section{Chætopleurophora rufithorax sp. nov.}

․ Length, $2.0 \mathrm{~mm}$. Black; the thorax above reddish brown, lighter at the extreme sides and indistinctly so as a streak on each side of the median line; pleuræ also brownish; scutellum paler, except at the base; front and middle legs entirely pale yellowish; hind legs pale at the base, blackened beyond the basal third of the femora and again brown on the tarsi; palpi fuscous. Halteres whitish. Wings weakly, but distinctly infuscated; heavy veins brown. Front minutely roughened, not shining; quadrate, or slightly longer than wide. Frontal bristles long and stout; postantennals inserted very near together; lower frontal row equidistant, the lateral ones very close to the eye-margin and slightly higher than the median ones; preocellar row of four forming a straight transverse line, equidistant from the lower row and the ocellar row. Median frontal line faintly indicated, ocellar tubercle distinct. Eyes pubescent. Antennæ unusually small, rounded; with a long, sparsely pubescent arista. Palpi very small, with moderately long bristles at tip, but those along the lower margin are weakly developed. Mesonotum subshining, with conspicuous minute hairs; one pair of dorsocentral bristles set very near to the base of the scutellum; sides of the mesonotum bristly behind, but only a couple of these bristles are long and stout. Propleura with two small, but conspicuous bristles at the posterior margin next to the 
spiracle and a few scattered small bristly hairs near them. Mesopleura with a large area of bristly hairs above, extending anteriorly almost to the spiracle and one unusually long, stout bristle near the posterior edge. Front tibiæ without any bristles before apex. Middle tibiæ with a pair of long bristles near the base, one at the basal fourth just anterior to the dorsal line and one at the basal third just inside the dorsal line; these bristles very stout and half as long as the tibia; at the apical fourth with a small anterodorsal bristle that does not extend to the tip of the tibia. Hind femur broad; hind tibiæ each with two long stout bristles, both just anterior to the dorsal line, one at the basal third and one just before the tip; also with three terminal spurs; the tibia with transverse rows comb-like bristles on the apical half of its inner surface although these are not so clearly comb-like as in some species and do not form rows on the basal half. Abdomen subopaque above, without noticeable bristly hairs, except at the sides of the second tergite; third tergite longer and narrower than the second; fourth very short, about four times as wide as long; fifth twice as long as the fourth, about twice as wide as long; sixth narrower and longer, about quadrate; seventh minute, not emarginate behind; genitalia with sparse bristly hairs, wings narrow, the costa less than half as long as the wing (35:75); first section of costa nearly twice as long as the second and third combined, third two-thirds as long as the second (20:6:4) costal fringe short and delicate; fourth vein weakly, evenly curved; fifth very faintly sinuate; seventh distinct.

Type from Ithaca, New York, Sept. 6, 1922.

This species is similar to the European C. erythronota Strobl. but differs at once by the narrower, opaque front which is wider than long and distinctly shining in the European species. Also the spine near the apex of the middle tibia is reduced to a very weak bristle whereas in C. erythronota it is exceedingly large, extending beyond the tip of the tibia. These comparisons are based on a female from Admont, Austria sent me many years ago by Strobl.

Chætopleurophora scutellata Brues.

Trans. American Entom. Soc., vol. 29, p. 344 (1904) (Phora). Malloch, Proc. U. S. Nat. Mus., vol. 43, p. 426 (1912) (Paraspiniphora). 
Brues, Bull. Mus. Comp. Zool., vol. 62, p. 499 (1919) (Paraspiniphora).

Schmitz, Monogr. Phoriden, p. 93 (1929) (Chœtocnemistoptera).

This species should be placed in the genus Chætopleurophora as it has a single large, backwardly directed bristle on the mesopleura in addition to the small hairs that clothe the upper portion of the mesopleura.

Chætopleurophora jamaicensis Brues.

Bull. American Mus. Nat. Hist., vol. 41, p. 431 (1919) (Paraspiniphora).

Schmitz, Monogr. Phoriden, p. 93 (1929) (Choetocnemistoptera).

This is likewise a Chætopleurophora, but as Schmitz has suggested should rank as a distinct species rather than as a subspecies. The bristling of the hind tibiæ is distinctive; in jamaicensis the anterodorsal bristle is paired with the first of the three dorsal bristles and in scutellata it is paired, or nearly so, with the second of the four dorsal bristles.

\section{Chætopleurophora multiseriata Aldrich.}

Trans. American Entom. Soc., vol. 29, p. 345 (1904) (Phora). Malloch, Proc., U. S. Nat. Mus., vol. 43, p. 438 (1912) (Paraspiniphora).

Schmitz, Monogr. Phoriden, p. 93 (1929) (Chotocnemistoptera).

This rather common and conspicuous North American species is also a Chætopleurophora, with the mesopleural bristle large and stout. 

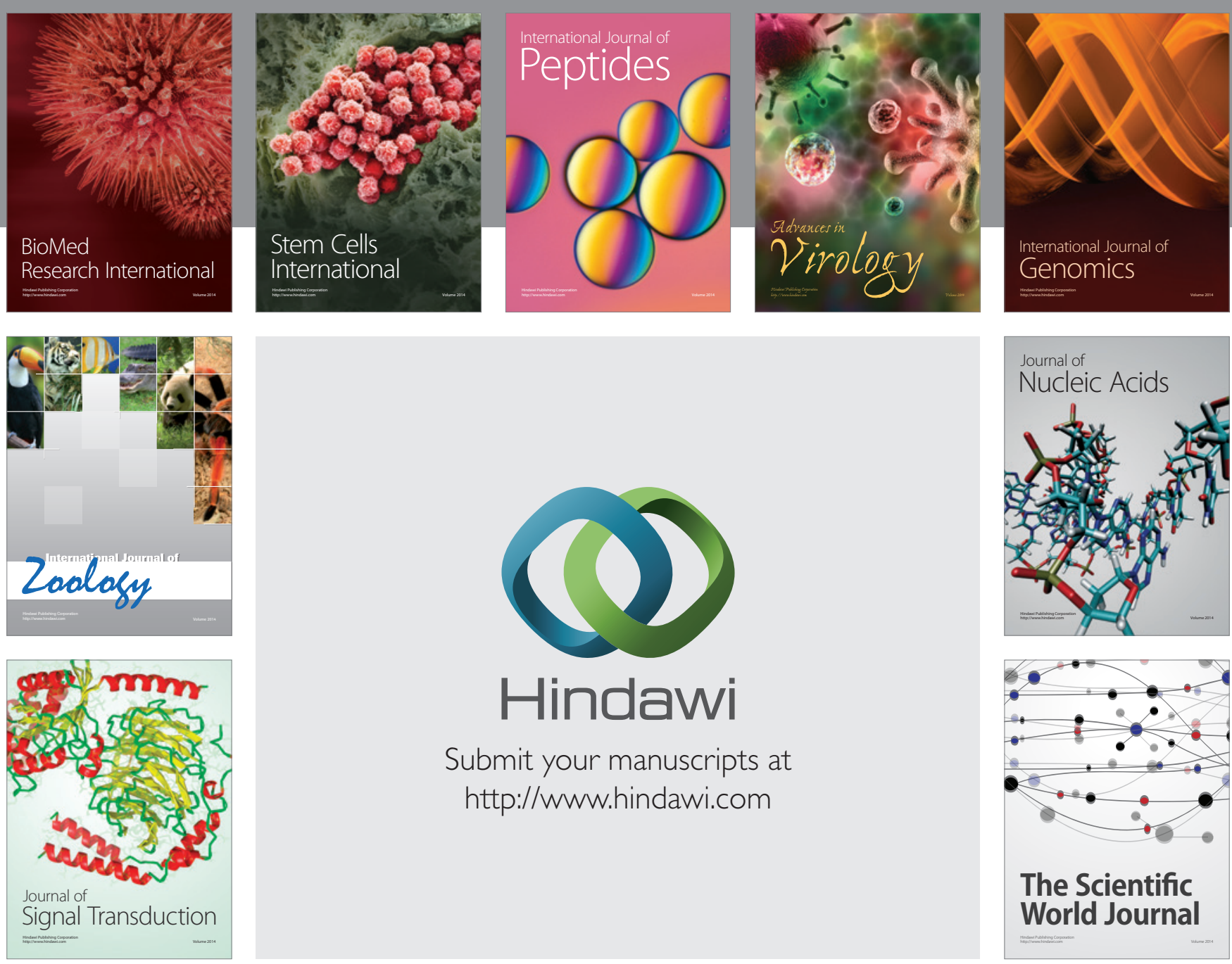

Submit your manuscripts at

http://www.hindawi.com
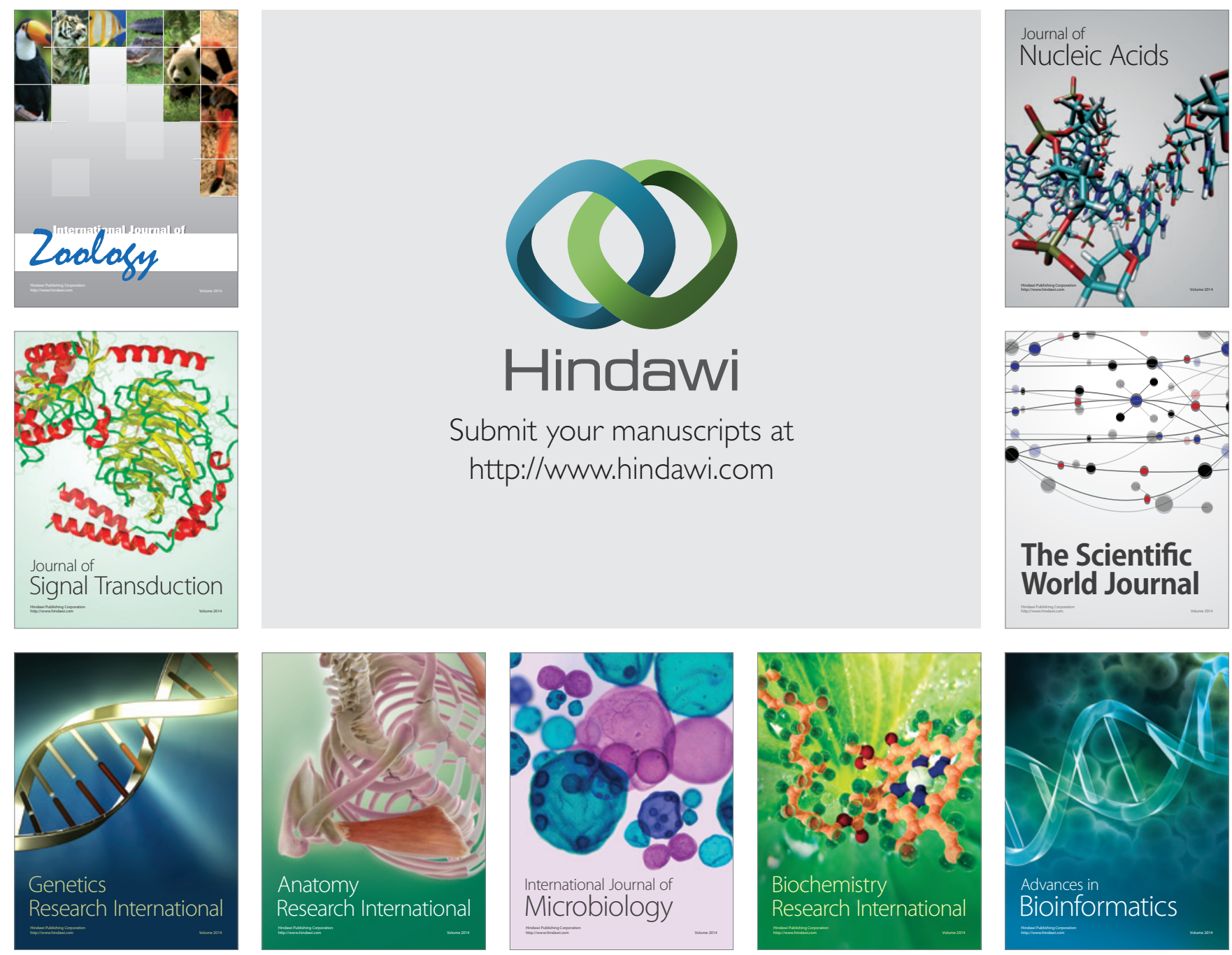

The Scientific World Journal
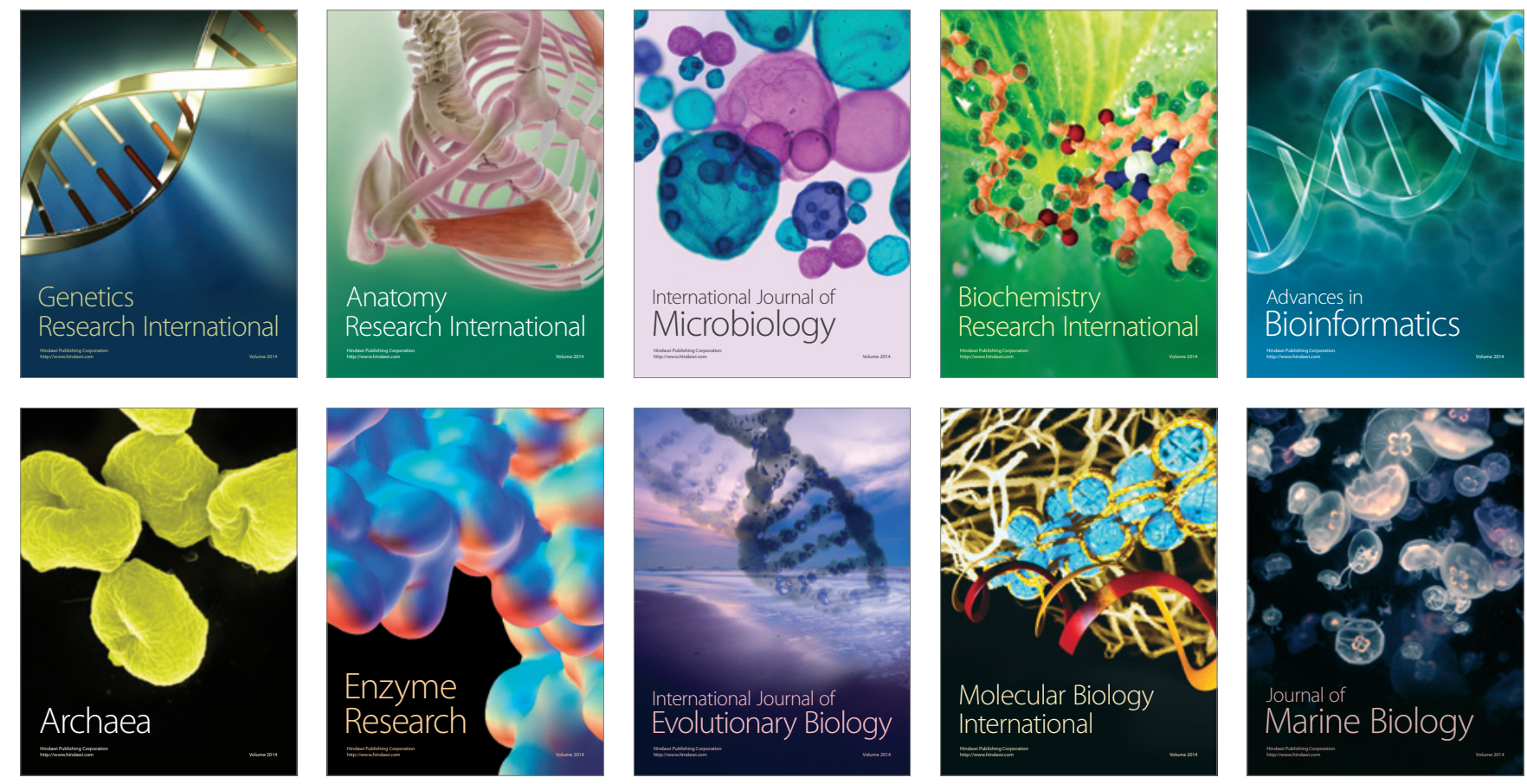